\title{
Saccharification of Biomass Using Whole Solid-State Fermentation Medium to Avoid Additional Separation Steps
}

\author{
Rosangela D. P. B. Pirota
}

Programa de Pós-graduação em Biotecnologia, Universidade Federal de São Carlos, 13565-905, São Carlos, SP, Brazil

Embrapa Instrumentação, Rua XV de Novembro 1452, 13560-970, São Carlos, SP, Brazil

\section{Flávio C. F. Baleeiro}

Departamento de Engenharia Química, Universidade Federal de São Carlos, 13565-905, São Carlos, SP, Brazil

Embrapa Instrumentação, Rua XV de Novembro 1452, 13560-970, São Carlos, SP, Brazil

\section{Cristiane S. Farinas}

Programa de Pós-graduação em Biotecnologia, Universidade Federal de São Carlos, 13565-905, São Carlos, SP, Brazil

Embrapa Instrumentação, Rua XV de Novembro 1452, 13560-970, São Carlos, SP, Brazil

DOI 10.1002/btpr.1811

Published online October 15, 2013 in Wiley Online Library (wileyonlinelibrary.com)

The enzymatic hydrolysis of steam-exploded sugarcane bagasse (SESB) was investigated using enzymatic extracts (EE) and whole fermentation media (WM), produced in-house, from Aspergillus niger 3T5B8 and Trichoderma reesei Rut-C30 cultivated on wheat bran under solid-state fermentation (SSF). A detailed and quantitative comparison of the different hydrolysis conditions tested was carried out using the Chrastil approach for modeling enzymatic reactions by fitting the experimental data of total reducing sugar (TRS) released according to hydrolysis time. Conversion of SESB using A. niger enzymatic complex were up to 3.2-fold higher (in terms of TRS) than T. reesei at similar enzyme loadings, which could be correlated to the higher $\beta$-glucosidase levels (up to 35-fold higher) of A. niger enzymatic complex. Conversion yields after $72 \mathrm{~h}$ exceeded $40 \%$ in terms of TRS when the WM was supplemented with a low dosage of a commercial enzyme preparation. When the combination of WM (from either T. reesei or A. niger) and commercial cellulase was used, the dosage of the commercial enzyme could be reduced by half, while still providing a hydrolysis that was up to $36 \%$ more efficient. Furthermore, SESB hydrolysis using either EE or WM resulted in similar yields, indicating that the enzyme extraction/filtration steps could be eliminated from the overall process. This procedure is highly advantageous in terms of reduced enzyme and process costs, and also avoids the generation of unnecessary effluent streams. Thus, the enzymatic conversion of SESB using the WM from SSF is cost-effective and compatible with the biorefinery concept. (C) 2013 American Institute of Chemical Engineers Biotechnol. Prog., 29:1430-1440, 2013

Keywords: enzymatic hydrolysis, cellulases, Trichoderma reesei, Aspergillus niger, biorefinery, saccharification, solid-state fermentation, whole medium, sugarcane bagasse

\section{Introduction}

Enzymatic conversion of the polysaccharides present in lignocellulosic biomass will be a key technology in future biorefineries. However, in order to make this process economically feasible, it is necessary to improve the efficiency of enzyme production, since the cost of the enzymatic cocktails significantly influences the viability of the overall process of biomass bioconversion into fuels and other chemicals. To this end, recent studies have aimed at increasing the efficiency of enzyme production by identifying novel

This article was published online on 15 October 2013.An error was subsequently identified. This notice is included in the online and print versions to indicate that both have been corrected 29 October 2013.

Correspondence concerning this article should be addressed to Cristiane S. Farinas at cristiane.farinas@embrapa.br. microbial strains ${ }^{1-3}$ and more efficient fermentation techniques, ${ }^{4-6}$ as well as strategies to recycle the enzymes. ${ }^{7-9}$ Onsite production of enzymes is another strategy that could be used to reduce costs, since there is less need to stabilize the enzyme preparations, which avoids the expenses associated with transport and long-term storage..$^{10-12}$

To break down plant cell wall components, an enzymatic cocktail containing cellulases, hemicellulases, and other accessory enzymes is required in order to achieve efficient hydrolysis. This type of enzymatic complex is produced by a wide variety of microorganisms (bacteria and fungi); however, the aerobic fungi especially are known for their high growth and protein secretion rates. ${ }^{13}$ Most commercial cellulase preparations are produced using filamentous fungi of the genera $T r i$ choderma and Aspergillus. The Trichoderma reesei fungus is known to be highly cellulolytic and is an important source of 
industrial cellulases, xylanases, and other cell wall-degrading enzymes. However, enzyme-prospecting research continues to identify opportunities to enhance the activity of $T$. reese $i$ enzyme preparations by supplementation with enzymatic diversity from other microbes. ${ }^{2}$ In the field of biotechnology, the fungus Aspergillus niger has been shown to be a highly efficient enzyme producer, and comparison of the genome sequences of $T$. reese $i$ and $A$. niger has shown that $A$. niger is more versatile in terms of the range of encoded cellulases, hemicellulases, and esterases. ${ }^{14}$

The use of solid-state fermentation (SSF) for industrial enzyme production has received increasing attention over the past 20 years due to the inherent advantages of this cultivation system. ${ }^{15,16}$ Many studies have described the use of SSF to produce enzymes involved in biomass deconstruction. ${ }^{16} \mathrm{SSF}$ is particularly advantageous for enzyme production by filamentous fungi, since it simulates the natural habitat of these microorganisms. From the environmental perspective, the benefit of $\mathrm{SSF}$ is related to the use of agro-industrial residues as solid substrate, acting as sources of both carbon and energy. ${ }^{17}$

In traditional SSF processes, after the cultivation period the enzymes synthesized by the microorganisms are extracted from the solid substrate by conventional solid-liquid extraction, with the final products after filtration being a liquid supernatant containing the enzymes of interest, which can be further concentrated, together with a solid residue. A potential way of avoiding production of this solid residue is to use the whole fermentation medium, containing the enzymes, mycelia, and the residual solid substrate, for the saccharification of lignocellulosic biomass such as sugarcane bagasse. A similar process configuration has been reported, using the whole submerged fermentation $(\mathrm{SmF})$ broth of $T$. reesei to improve the performance of a simultaneous saccharification and fermentation process. ${ }^{18}$ Whole $\mathrm{SmF}$ broth produced using $T$. reesei and $T$. atrovide has also been employed for the hydrolysis of pretreated spruce, ${ }^{19}$ and whole $\mathrm{SmF}$ broth of $T$. reesei ZU-02 has been used for the hydrolysis of corn cob. ${ }^{19,20}$ In addition, Sorensen et al. ${ }^{11}$ demonstrated the use of whole SSF cultivation medium for the hydrolysis of wet oxidized wheat straw.

In Brazil, the production of first generation bioethanol was developed using sugarcane as feedstock, and the country is now one of the world's most competitive producers of bioethanol. ${ }^{21}$ The production of second generation bioethanol from sugarcane bagasse is an important sustainable means of increasing yields. For such application, developments on sugarcane bagasse pretreatment using steam explosion, ${ }^{22-24}$ hydrother$\mathrm{mal}^{25}$ ionic liquids, ${ }^{26-28}$ dilute acid, ${ }^{29,30}$ lime, ${ }^{31}$ organosolv, ${ }^{32}$ and chemithermomechanical processing ${ }^{33}$ have been reported. Nevertheless, steam explosion has been considered one of the preferred technologies for sugarcane bagasse pretreatment. ${ }^{34}$ For the enzymatic hydrolysis of sugarcane bagasse, configurations using either commercial or on-site produced enzyme preparations have been described. ${ }^{35-37}$ However, to the best of our knowledge, there have been no studies concerning the enzymatic hydrolysis of sugarcane bagasse using the whole SSF cultivation medium, with evaluation of the contribution of mycelia-bound enzymes to the process. Elimination of the SSF extraction/filtration steps during enzyme production would be highly advantageous in terms of reduced process costs, and would also avoid the production of unnecessary effluent streams, hence being compatible with the biorefinery concept.

The present work investigates the enzymatic hydrolysis of steam-exploded sugarcane bagasse (SESB) using the enzyme extracts and whole fermentation media of Aspergillus niger
3T5B8 and Trichoderma reesei Rut-C30 cultivated on wheat bran under selected SSF conditions. The hydrolysis yields were compared with those obtained using a commercial cellulase preparation as well as combinations of different enzyme sources. To achieve a more detailed and quantitative comparison of the different hydrolysis conditions tested, the Chrastil approach for modeling enzymatic reactions was used to fit the experimental data of total reducing sugar released according to hydrolysis time.

\section{Materials and Methods}

\section{Microorganisms}

The microorganisms used in this study were a mutant strain of Aspergillus niger (A. niger 3T5B8) from the Embrapa Food Technology Collection (Rio de Janeiro, Brazil) and a strain of Trichoderma reesei ( $T$. reesei Rut-C30) from the American Type Culture Collection. Stock cultures were stored at $4{ }^{\circ} \mathrm{C}$ on potato dextrose agar (PDA) slants. The cultures were revitalized and maintained on PDA slants at $32^{\circ} \mathrm{C}$ for 5 days prior to inoculation.

\section{Lignocellulosic materials}

Solid-state fermentation (SSF) cultivations were carried out using wheat bran (Claro Agricopecuária, São Carlos, Brazil) as solid substrate. The enzymatic hydrolysis experiments employed steam-exploded sugarcane bagasse (SESB) kindly provided by CTBE (Campinas, Brazil). The composition of the SESB used in all hydrolysis experiments, in terms of cellulose, hemicellulose, and lignin, was $51.7 \% \pm 0.6 \%$, $8.9 \% \pm 0.1 \%$, and $34.3 \% \pm 0.3 \%$, respectively. ${ }^{10}$

\section{Selection of conditions for SSF cultivations}

Cultivations for the selection of SSF process conditions were carried out in $250 \mathrm{~mL}$ Erlenmeyer flasks for $72 \mathrm{~h}$, using wheat bran as solid substrate. The solid medium was sterilized by autoclaving at $121^{\circ} \mathrm{C}$ for $20 \mathrm{~min}$ before inoculation. A spore suspension volume corresponding to $10^{7}$ conidia per $\mathrm{g}$ of dry solid medium was inoculated into the solid medium by gently stirring with a glass rod until a uniform mixture was obtained. The strategy adopted for selection of SSF conditions was to evaluate each variable individually, and then select the best value for incorporation in the next variable selection step. Initially, cultivations were carried out at $35^{\circ} \mathrm{C}$ with different moisture levels $(50,60,70$, and $80 \%)$, adjusted using a nutrient solution. ${ }^{38}$ After selection of the most favorable moisture content, different temperatures (28, $30,32,35$, and $37^{\circ} \mathrm{C}$ ) were evaluated using selected initial moisture contents of $80 \%$ for the A. niger strain and $60 \%$ for the $T$. reesei strain. After a $72 \mathrm{~h}$ cultivation period, the enzymes were extracted and analyzed as described in Enzyme Extraction and Analytical Measurements sections, respectively. The mean values obtained for each condition were analyzed statistically using Origin (v. 8.0) software.

\section{Temporal profiles of enzymatic production under the selected SSF conditions}

In the kinetic study, SSF cultivations were carried out in $250 \mathrm{~mL}$ Erlenmeyer flasks for $120 \mathrm{~h}$, with samples (whole flasks) being withdrawn at 24-h intervals. The SSF conditions selected for $A$. niger were an initial wheat bran 
moisture content of $80 \%$ and a temperature of $28^{\circ} \mathrm{C}$, while for $T$. reesei an initial moisture content of $60 \%$ and $35^{\circ} \mathrm{C}$ were selected. In the hydrolysis experiments, cultivations were carried out under these same conditions, but for a period of $48 \mathrm{~h}$. After the cultivation periods, the enzymes were extracted and analyzed as described in Enzyme Extraction and Analytical Measurements sections, respectively. The whole fermentation media were also used in the hydrolysis experiments, as described in Enzymatic Hydrolysis section. All cultivation experiments were carried out in triplicate, and the data were calculated as means \pm standard deviations.

\section{Enzyme extraction}

After the cultivation period, the enzymes were extracted by adding a sufficient volume of $0.05 \mathrm{~mol} \mathrm{~L}^{-1}$ sodium citrate buffer, at $\mathrm{pH} 4.8$, to achieve a solid/liquid ratio of 1:10 (w/v). The suspension was stirred at $120 \mathrm{rpm}$ for $30 \mathrm{~min}$ at room temperature, and the crude enzymatic solution was recovered by filtration followed by centrifugation at $10,000 \mathrm{~g}$ at $4^{\circ} \mathrm{C}$ for $20 \mathrm{~min}$. The enzymatic extracts were stored at $-18^{\circ} \mathrm{C}$ prior to the analyses. In the hydrolysis experiments, the crude enzymatic extract was mixed with the solid material to be hydrolyzed, immediately after the extraction/filtration step.

\section{Enzymatic hydrolysis}

The enzymatic hydrolysis experiments were carried out in $500 \mathrm{~mL}$ Erlenmeyer flasks containing $5 \mathrm{~g}$ of SESB and 100 $\mathrm{mL}$ of sodium citrate buffer at $\mathrm{pH}$ 4.8. The suspension was initially acclimatized at $50^{\circ} \mathrm{C}$ for $4 \mathrm{~h}$ with $200 \mathrm{rpm}$ agitation. Subsequently, $5 \mathrm{~g}$ of the previously fermented wheat bran SSF material (as described in Temporal Profiles of Enzymatic Production Under the Selected SSF Conditions section) was added, and the mixture was incubated at $50^{\circ} \mathrm{C}$ for $72 \mathrm{~h}$ with agitation at $200 \mathrm{rpm}$. Samples were removed at 0, 6, 12, 24, 48 , and $72 \mathrm{~h}$ for quantification of the glucose and total reducing sugar released. When the hydrolysis was conducted with crude enzymatic extract (EE) instead of the whole fermentation medium (WM), only $50 \mathrm{~mL}$ of sodium citrate buffer $(\mathrm{pH}$ 4.8) was added to the SESB for acclimatization, after which the final volume was completed to $100 \mathrm{~mL}$ by adding $50 \mathrm{~mL}$ of the EE from the A. niger or T. reesei SSF cultivations. All hydrolysis experiments were carried out using a $5 \%(\mathrm{w} / \mathrm{v})$ solids loading, in terms of SESB. In addition, a commercial enzyme preparation (Cellic Cetec2 $\AA$, kindly donated by Novozymes A/S, Denmark) was used either alone or in different combinations with the other enzyme sources, for comparative purposes and to evaluate the effect of synergism between the SSF medium and the enzymatic extract on the hydrolysis of SESB. The commercial cellulase preparation was diluted sufficiently to achieve an enzymatic activity (in terms of FPU/mL) equivalent to that of the crude fungal enzyme extracts. In all experiments, sodium azide $(0.1 \%$, w/v) was added in order to prevent fungal development during the hydrolysis step. All hydrolysis experiments were carried out in triplicate, and the data were calculated as means \pm standard deviations. The mean values obtained for each condition were analyzed statistically using the Origin software.

\section{Kinetic modeling of the enzymatic hydrolysis}

The Chrastil approach for modeling enzymatic reactions was used to fit the experimental data of reducing sugar release according to hydrolysis time. ${ }^{39}$ This model is described by,

$$
P=P_{\infty}\left(1-e^{\left(-k E_{0} t\right)}\right)^{n}
$$

where $P$ and $P_{\infty}$ are the products that diffused at time $t$ and at equilibrium, respectively, $k$ is a rate constant proportional to the diffusion coefficient, $E_{0}$ is the initial enzyme concentration, and $n$ is a constant related to the diffusion resistance that depends on the sterical structure of the system. For the present system, $P$ is expressed in grams of TRS (total reducing sugar) per liter, $P_{\infty}$ is the potential (theoretical) total reducing sugar that could be obtained from the cellulose and hemicellulose in the $\operatorname{SESB}\left(33.6 \mathrm{~g} \mathrm{~L}^{-1}\right)$, and $E_{0}$ is the initial enzyme loading of the hydrolysis (FPU/L). The model parameters for the different hydrolysis conditions were obtained by fitting Eq. 1 to the SESB enzymatic hydrolysis experimental data by nonlinear regression using the Origin software.

\section{Analytical measurements}

The activities of FPase and endoglucanase were determined according to the procedure recommended by the IUPAC Commission on Biotechnology, with modifications. ${ }^{1}$ The activity of xylanase was measured according to the methodology described by Bailey and Poutanen. ${ }^{40}$ Here, one unit of activity corresponds to $1 \mu \mathrm{mol}$ of reducing sugar released per minute per $\mathrm{mL}$, under the reaction conditions. Quantification of the reducing groups employed the dinitrosalicylic acid (DNS) method. ${ }^{41}$ The $\beta$-glucosidase activity was determined using cellobiose (Sigma, St. Louis, USA) as substrate and quantifying the sugars released using an enzymatic kit for glucose measurement (Doles, Goiânia, Brazil). The results were expressed as activity units per mass of initial dry solid substrate (IU $\mathrm{g}^{-1}$ ). In the hydrolysis experiments, glucose and total reducing sugar were measured using the enzymatic kit for glucose measurement and the DNS method, respectively. Total protein was measured using the Bradford method. ${ }^{42}$

\section{Results and Discussion}

\section{Effect of substrate initial moisture content on enzyme production under SSF}

Enzyme production by the fungi was characterized for cultivations performed under different SSF process conditions in order to identify a condition that offered high enzymatic production and that could be used in the hydrolysis experiments. First, the influence of substrate initial moisture content on enzyme production was investigated by cultivating the fungi for $72 \mathrm{~h}$ at $35^{\circ} \mathrm{C}$ using different initial moisture contents $(50,60,70$, and $80 \%)$ of the wheat bran substrate. Comparisons of the influence of moisture content on the production of xylanase, endoglucanase, $\beta$-glucosidase, and FPase by $A$. niger $3 \mathrm{~T} 5 \mathrm{~B} 8$ and $T$. reseei Rut-C30 are presented in Table 1.

In general, there was a positive effect of moisture content on enzyme production by $A$. niger 3T5B8 (Table 1). While the activities of xylanase, endoglucanase, and FPase were higher when an initial moisture content of $80 \%$ was used, the production of $\beta$-glucosidase was favored by a moisture content of $50 \%$. Nevertheless, statistical analysis using the Tukey comparison test $(P<0.05)$ indicated that the population means of the activities obtained using higher moisture contents were not significantly different. This is a valuable finding in terms of bioprocess development, since it implies 
Table 1. Influence of Initial Substrate Moisture Content on Enzymatic Production by A. niger 3T5B8 and T. reseei Rut-C30 Cultivated Under SSF

\begin{tabular}{|c|c|c|c|c|}
\hline Initial Moisture (\%) & Xylanase $\left(\mathrm{IUg}^{-1}\right)$ & Endoglucanase $\left(\mathrm{IUg}^{-1}\right)$ & $\beta$-glucosidase $\left(\mathrm{IUg}^{-1}\right)$ & FPase $\left(\mathrm{IUg}^{-1}\right)$ \\
\hline \multicolumn{5}{|l|}{ A. niger 3Т5B8 } \\
\hline 50 & $801.1 \pm 18.6^{\mathrm{a}}$ & $176.7 \pm 15.6^{\mathrm{b}}$ & $72.5 \pm 1.7^{\mathrm{a}}$ & $0.39 \pm 0.03^{\mathrm{a}}$ \\
\hline 60 & $811.4 \pm 57.1^{\mathrm{a}}$ & $179.9 \pm 1.3^{\mathrm{b}}$ & $55.6 \pm 12.4^{\mathrm{a}}$ & $0.43 \pm 0.06^{\mathrm{a}}$ \\
\hline 70 & $823.6 \pm 10.6^{\mathrm{a}}$ & $201.4 \pm 11.4^{\mathrm{a}, \mathrm{b}}$ & $54.2 \pm 0.5^{\mathrm{a}}$ & $0.44 \pm 0.02^{\mathrm{a}}$ \\
\hline 80 & $836.7 \pm 15.9^{\mathrm{a}}$ & $226.3 \pm 3.2^{\mathrm{a}}$ & $52.0 \pm 8.8^{\mathrm{a}}$ & $0.51 \pm 0.04^{\mathrm{a}}$ \\
\hline \multicolumn{5}{|l|}{ T. reesei Rut-C30 } \\
\hline 50 & $575.6 \pm 65.5^{\mathrm{a}}$ & $109.6 \pm 15.7^{\mathrm{a}}$ & $2.5 \pm 0.4^{\mathrm{a}}$ & $0.49 \pm 0.06^{\mathrm{a}}$ \\
\hline 60 & $378.9 \pm 43.2^{\mathrm{b}}$ & $146.5 \pm 24.5^{\mathrm{a}}$ & $1.8 \pm 0.1^{\mathrm{b}, \mathrm{c}}$ & $0.59 \pm 0.1^{\mathrm{a}}$ \\
\hline 70 & $216.7 \pm 1.7^{\mathrm{c}}$ & $43.4 \pm 4.0^{\mathrm{b}}$ & $1.4 \pm 0.02^{\mathrm{c}}$ & $0.28 \pm 0.04^{\mathrm{b}}$ \\
\hline 80 & $155.7 \pm 5.1^{\mathrm{c}}$ & $35.1 \pm 2.1^{\mathrm{b}}$ & $0.8 \pm 0.1^{\mathrm{d}}$ & $0.23 \pm 0.02^{\mathrm{b}}$ \\
\hline
\end{tabular}

Means with different letters are significantly different (Tukey's test, $P<0.05$ ).

Table 2. Influence of Temperature on Enzymatic Production by A. niger 3T5B8 and T. reseei Rut-C30 Cultivated Under SSF

\begin{tabular}{|c|c|c|c|c|}
\hline Temperature $\left({ }^{\circ} \mathrm{C}\right)$ & Xylanase $\left(\mathrm{IUg}^{-1}\right)$ & Endoglucanase $\left(\mathrm{IUg}^{-1}\right)$ & $\beta$-glucosidase $\left(\mathrm{IUg}^{-1}\right)$ & FPase $\left(\mathrm{IUg}^{-1}\right)$ \\
\hline \multicolumn{5}{|l|}{ A. niger 3Т5B8 } \\
\hline 28 & $2393.6 \pm 35.8^{\mathrm{a}}$ & $202.7 \pm 45.3^{\mathrm{b}}$ & $28.5 \pm 0.09^{\mathrm{b}}$ & $0.69 \pm 0.006^{\mathrm{a}, \mathrm{b}, \mathrm{c}}$ \\
\hline 30 & $2204.0 \pm 144.7^{\mathrm{a}}$ & $241.4 \pm 3.6^{\mathrm{b}}$ & $53.1 \pm 0.03^{\mathrm{a}}$ & $0.83 \pm 0.02^{\mathrm{a}}$ \\
\hline 32 & $1494.6 \pm 112.8^{\mathrm{b}}$ & $253.1 \pm 17.8^{\mathrm{b}}$ & $58.1 \pm 0.26^{\mathrm{a}}$ & $0.77 \pm 0.05^{\mathrm{a}, \mathrm{b}}$ \\
\hline 35 & $836.7 \pm 15.9^{\mathrm{c}}$ & $260.5 \pm 47.7^{\mathrm{b}}$ & $54.2 \pm 0.18^{\mathrm{a}}$ & $0.56 \pm 0.06^{\mathrm{b}, \mathrm{c}}$ \\
\hline 37 & $704.4 \pm 49.1^{\mathrm{c}}$ & $332.7 \pm 18.6^{\mathrm{a}}$ & $54.5 \pm 0.03^{\mathrm{a}}$ & $0.51 \pm 0.03^{\mathrm{c}}$ \\
\hline \multicolumn{5}{|l|}{ T. reesei Rut-C30 } \\
\hline 28 & $620.2 \pm 56.3^{\mathrm{a}}$ & $40.4 \pm 5.5^{\mathrm{d}}$ & $0.9 \pm 0.4^{\mathrm{b}, \mathrm{c}}$ & $0.35 \pm 0.1^{\mathrm{b}}$ \\
\hline 30 & $520.8 \pm 69.3^{\mathrm{a}, \mathrm{b}}$ & $69.8 \pm 5.6^{\mathrm{c}}$ & $1.0 \pm 0.1^{\mathrm{b}}$ & $0.40 \pm 0.03^{\mathrm{b}}$ \\
\hline 32 & $440.1 \pm 27.0^{\mathrm{b}, \mathrm{c}}$ & $102.1 \pm 6.6^{\mathrm{b}}$ & $1.5 \pm 0.03^{\mathrm{a}}$ & $0.54 \pm 0.3^{\mathrm{a}}$ \\
\hline 35 & $381.9 \pm 9.4^{\mathrm{c}}$ & $152.3 \pm 4.0^{\mathrm{a}}$ & $1.8 \pm \mathbf{0 . 0 3}^{\mathrm{a}}$ & $0.63 \pm 0.2^{\mathrm{a}}$ \\
\hline 37 & $246.8 \pm 35.6^{\mathrm{d}}$ & $80.3 \pm 10.8^{c}$ & $0.6 \pm 0.1^{\mathrm{c}}$ & $0.38 \pm 0.03^{\mathrm{b}}$ \\
\hline
\end{tabular}

Means with different letters are significantly different (Tukey's test, $P<0.05$ ).

that cellulase and xylanase biosynthesis by A. niger 3T5B8 was not very sensitive to variations in substrate initial moisture content. Among the various operational parameters that affect SSF process efficiency, moisture content is one of the most important. If it is too high, the void spaces in the solids are filled with water, resulting in oxygen limitation. At the other extreme, if the moisture content is too low, the growth of the microorganism will be hindered. ${ }^{17}$ Consequently, identification of the optimal moisture content for each solid substrate is crucial for the promotion of favorable growing conditions, and hence for satisfactory metabolite production. However, the optimal moisture content value depends on both the type of solid substrate and the microorganism used. ${ }^{17}$ It is also important to note that the moisture content can vary during the course of the cultivation period, since microorganism growth and respiration result in heat release. The discovery of a strain that is not very sensitive to variations in substrate initial moisture content, as appears to be the case for A. niger 3T5B8, can greatly assist process development. The $T$. reesei strain seemed to be more sensitive to variations in the substrate moisture content (Table 1). Enzyme production by $T$. reesei was generally higher when the moisture content was low (50 or $60 \%$ ), and decreased significantly at higher moisture levels. On the basis of these results, initial substrate moisture contents of 80 and $60 \%$ were selected in subsequent studies to evaluate the effect of temperature on enzymatic production by A. niger and T. reesei, respectively.

The effect of the initial substrate moisture content on the production of cellulase and xylanase enzymes by Aspergillus and Trichoderma strains cultivated under SSF has been described previously. Delabona et al. ${ }^{43}$ used a strain of $A$. niger (P47C3) isolated from the Amazon Forest to evaluate the effect of moisture content on endoglucanase production, and found that a reduction of the moisture content of wheat bran from 70 to $50 \%(\mathrm{w} / \mathrm{w})$ resulted in a 2.5 -fold improvement in endoglucanase production. Pal and Khanum ${ }^{44}$ compared xylanase production by $A$. niger cultivated under SSF for six moisture levels ranging from 55 to $80 \%$. The highest production of xylanase was obtained for a moisture content of $70 \%$, and either low or high initial moisture content significantly decreased enzyme production. Singhania et al. ${ }^{45}$ investigated the influence of process parameters on the production of cellulase by $T$. reesei Rut-C30 grown on wheat bran under SSF, and found similar effects of the initial moisture content of the medium on enzyme production.

\section{Effect of temperature on enzyme production under SSF}

Temperature is another important variable that affects microbial growth under SSF, hence influencing product formation. SSF cultivations were carried out at temperatures of $28,30,32,35$, and $37^{\circ} \mathrm{C}$, using wheat bran with fixed initial moisture contents of $80 \%$ for A. niger and $60 \%$ for T. reesei, as selected previously. Comparisons of the influence of temperature on xylanase, endoglucanase, $\beta$-glucosidase, and FPase production by $A$. niger 3 T5B 8 and $T$. reseei Rut-C30 are presented in Table 2 .

The effect of temperature on enzymatic production by $A$. niger varied for each of the enzymes analyzed (Table 2). For xylanase, a higher temperature had a significant negative effect, since production decreased from $2396.3 \mathrm{IU} \mathrm{g}^{-1}$ at $28^{\circ} \mathrm{C}$ to $704.4 \mathrm{IU} \mathrm{g}^{-1}$ at $37^{\circ} \mathrm{C}$, a 3.4 -fold reduction. Conversely, endoglucanase production was favored by an increase in temperature, with the highest value $\left(332.7 \mathrm{IU} \mathrm{g}^{-1}\right)$ achieved at $37^{\circ} \mathrm{C}$. The highest production of $\beta$-glucosidase was achieved at $32^{\circ} \mathrm{C}$, while maximum FPase activity was observed at $30^{\circ} \mathrm{C}$. In the case of $T$. reesei, there was greater production of cellulases 
(endoglucanase, $\beta$-glucosidase, and FPase) at $35^{\circ} \mathrm{C}$, while xylanase production was higher at $28^{\circ} \mathrm{C}$.

The influence of temperature on cellulase production has been reported for other Aspergillus strains cultivated under SSF. Jecu ${ }^{46}$ studied the effect of temperatures between 25 and $37^{\circ} \mathrm{C}$ on endoglucanase production by $A$. niger, and found that the optimum for endoglucanase production was in the range $28-34^{\circ} \mathrm{C}$. Singhania et al. ${ }^{45}$ investigated the effect of temperature on cellulase production by T. reesei Rut C-30 cultivated on wheat bran under SSF, and also found that the incubation temperature positively influenced the production of cellulase by this strain.

Similar to the effect of substrate moisture content, the characterization of each particular microorganism in terms of the influence of temperature on the kinetics of growth and product formation is essential for SSF bioprocess development. Based on the results, SSF cultivation using an initial moisture content of $80 \%$ and a temperature of $28^{\circ} \mathrm{C}$ was used to evaluate the kinetic profile of enzymatic production by $A$. niger during a cultivation period of $120 \mathrm{~h}$, while an initial moisture content of $60 \%$ and a temperature of $35^{\circ} \mathrm{C}$ were selected for $T$. reesei.

\section{Temporal profiles of enzyme production under the selected SSF conditions}

The temporal profiles of enzyme production over a 120 -h period of SSF cultivation under the selected conditions are illustrated in Figures 1a,b for A. niger 3T5B8 and T. reesei Rut-C30, respectively. For both fungi, peak production of the majority of the enzymes occurred between 48 and $96 \mathrm{~h}$ of cultivation. However, the time of maximum enzymatic production varied for each enzyme, as well as between the two fungal strains, with the exception of xylanase, which presented a maximum value after $48 \mathrm{~h}$ of cultivation for both $A$. niger (3382.5 $\mathrm{IU} \mathrm{g}^{-1}$ ) and $T$. reesei $\left(768.4 \mathrm{IU} \mathrm{g}^{-1}\right.$ ). Here, it is interesting to note the large difference between the amounts of xylanase enzymes synthesized by these two fungi, with $A$. niger secreting 4.4-fold more xylanase than $T$. reesei, under the conditions used. In terms of FPase, the activity values were similar for both fungi, although the maximum value was achieved after $48 \mathrm{~h}$ for $T$. reesei $(0.76$ $\left.\mathrm{IU} \mathrm{g}^{-1}\right)$ and only after $72 \mathrm{~h}$ for $A$. niger $\left(0.64 \mathrm{IU} \mathrm{g}^{-1}\right)$. The endoglucanase maxima differed in terms of both time and magnitude, since the amount secreted by A. niger after $96 \mathrm{~h}$ (369.3 IU g ${ }^{-1}$ ) was 2.3 -fold higher than the amount secreted by $T$. reesei after $72 \mathrm{~h}\left(158.2 \mathrm{IU} \mathrm{g}^{-1}\right)$. The synthesis of $\beta$ glucosidase also differed between the fungi in terms of both the time at which maximum production occurred and the amount produced. However, the difference between the amounts of enzyme secreted was much larger; $T$. reesei secreted a maximum of $1.6 \mathrm{IU} \mathrm{g}^{-1}$ of $\beta$-glucosidase after $120 \mathrm{~h}$ of cultivation, while the production of $\beta$-glucosidase by $A$. niger was almost 35 -fold higher, with $55 \mathrm{IU} \mathrm{g}^{-1}$ achieved after $96 \mathrm{~h}$ of cultivation.

The superiority of $A$. niger strains for $\beta$-glucosidase production, compared to Trichoderma strains, was expected, but the magnitude of the difference was unforeseen. Trichoderma reese $i$ is one of the most productive cellulolytic fungi, and the $T$. reesei Rut-C30 strain is one of the most studied and best characterized. ${ }^{47}$ Nonetheless, the amount of $\beta$ glucosidase secreted by Trichoderma reesei is not sufficient for efficient biomass conversion, ${ }^{13}$ because the complete conversion of cellulose into glucose is dependent on the
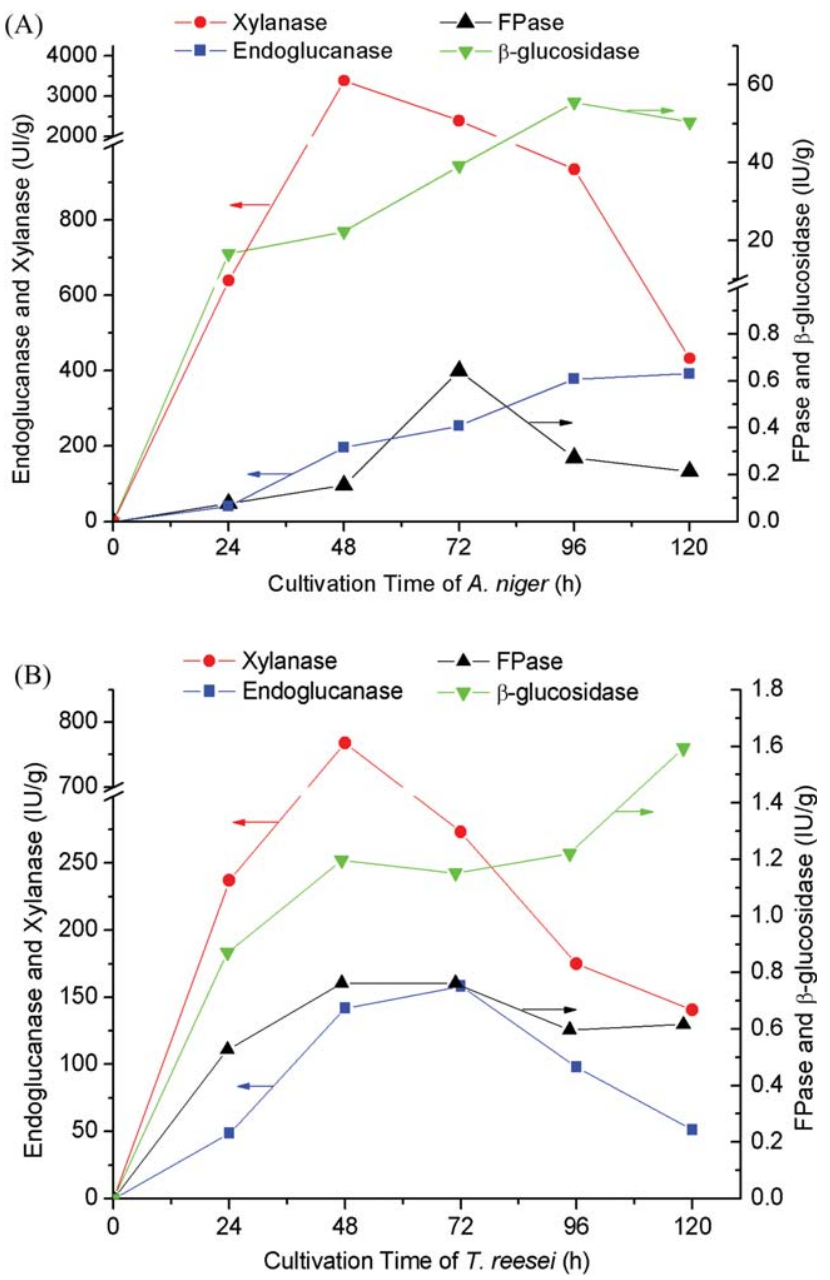

Figure 1. Kinetic profiles of enzyme production over a period of $120 \mathrm{~h}$ under SSF for (A) A. niger 3T5B8 and (B) T. reesei Rut-C30.

amount of active $\beta$-glucosidase. In addition, since $\beta$ glucosidase activity reduces the inhibitory effects of cellobiose, which is the end-product of exo- and endoglucanase activities, a suitable proportion of each of these enzymes is crucial for an efficient hydrolysis. ${ }^{13}$ The importance of large amounts of $\beta$-glucosidase on cellulose hydrolysis can also be correlated to the significant impact of the inhibition and deactivation of $\beta$-glucosidase by the phenolic compounds generated during biomass pretreatment. ${ }^{48}$ Besides the quantitative difference observed here between $\beta$-glucosidase from $A$. niger and $T$. reesei, it has been previously reported that $\beta$-glucosidase from $T$. reese $i$ is more susceptible to inhibition as well as deactivation by phenolic compounds than $\beta$ glucosidase from $A$. niger. ${ }^{49,50}$ Thus, the combination of $T$. reesei and $A$. niger enzymatic extracts may provide an enzyme mixture which is likely more resistant to inhibition and deactivation than enzyme derived from $T$. reesei alone. $\beta$-glucosidase production by Aspergillus strains such as $A$. niger has often been used to supplement commercial enzymatic cocktails. ${ }^{13,47}$

Overall, these results demonstrate the considerable potential of the A. niger 3T5B8 strain for the production of glycosyl hydrolases, since it showed a significantly higher enzymatic biosynthesis capacity when compared to the wellestablished cellulolytic strain $T$. reesei Rut-C30. Based on the results, the SESB hydrolysis experiments were conducted 

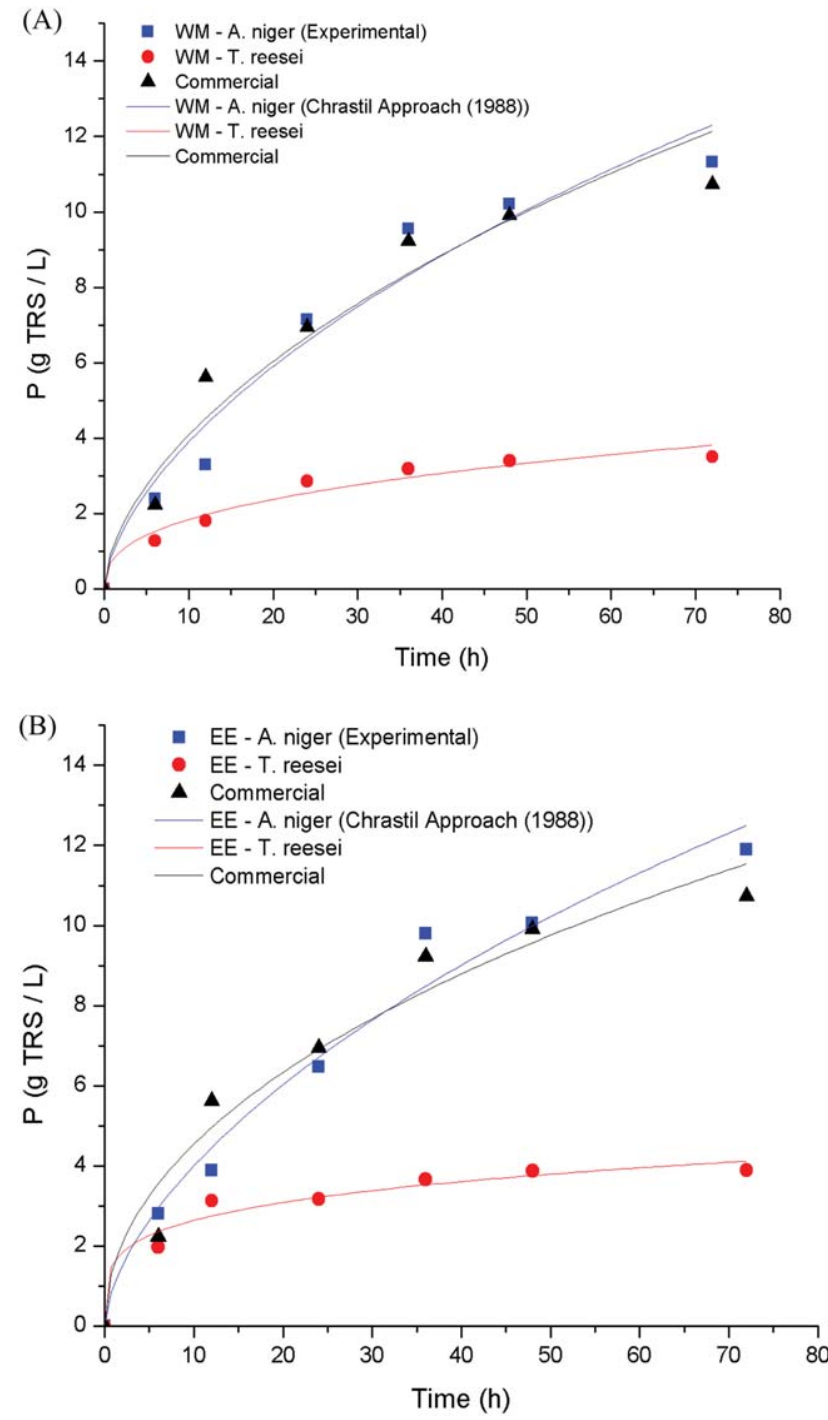

Figure 2. Temporal profiles of the concentrations of total reducing sugar released during the hydrolysis of pretreated sugarcane bagasse (SESB) using (A) the whole fermentation media (WM) from $A$. niger 3T5B8 and $T$. reesei Rut-C30, and the commercial preparation, and (B) the enzymatic extracts (EE) and the commercial preparation.

using 48-h cultivations of both fungi under the selected SSF conditions $\left(28^{\circ} \mathrm{C}\right.$ with an initial moisture content of $80 \%$ for A. niger, and $35^{\circ} \mathrm{C}$ with an initial moisture content of $60 \%$ for T. reesei).

\section{Temporal profiles and modeling of the enzymatic hydrolysis step}

The catalytic efficiencies of the enzymes produced by $A$. niger 3T5B 8 and $T$. reesei Rut-C30 cultivated under SSF were evaluated during the hydrolysis of pretreated sugarcane bagasse (SESB). Two different experimental configurations were employed: (1) The whole fermentation media (WM) obtained after $48 \mathrm{~h}$ of cultivation under the previously selected conditions was mixed with the SESB, without separating the enzymes from the fungal mycelia; (2) The SESB was mixed with the enzymatic extract (EE) obtained from the extraction and filtration procedures that followed the SSF cultivations carried out under the same selected conditions.
Table 3. Total Enzymatic Activities of A. niger 3T5B8 and T. reesei Rut-C-30 Extracts, and a Commercial Preparation, Used for SESB Hydrolysis

\begin{tabular}{lccc}
\hline Enzymatic & A. niger & T. reesei & \\
Activity (IU) & 3T5B8 & Rut C-30 & Commercial \\
\hline Xylanase & 16900 & 3840 & 1820 \\
Endoglucanase & 979 & 710 & 1730 \\
$\beta$-glucosidase & 110 & 6.0 & 468 \\
FPase & 0.75 & 3.9 & 4.7
\end{tabular}

In addition, experiments were conducted in order to evaluate the synergistic effect of different combinations of enzyme sources, and the possible use of the enzymes produced under SSF for supplementation of commercial enzyme cocktails. These experiments employed the enzymes present in the $\mathrm{WM}$ and EE from either $A$. niger or $T$. reesei in different combinations with a low dosage of a commercial enzyme preparation. The aim of these trials was to determine whether it was possible to reduce the quantity of commercial enzymes by using enzymes produced in-house, and whether the WM or the EE was preferable in terms of hydrolysis efficiency when used in combination with the commercial preparation.

Figure 2 presents the temporal profiles of total reducing sugar (TRS) released during the hydrolysis of SESB using the A. niger 3T5B8 or T. reesei Rut-C30 enzymes present in the whole fermentation media (WM) (Figure 2a) and in the enzymatic extracts (EE) (Figure 2b). For comparison, the graphs also include the SESB hydrolysis results obtained using the commercial preparation. Table 3 lists the total enzymatic activities of the EE obtained from both fungi under the selected cultivation conditions, as well as the total enzymatic activity of the commercial preparation. The latter was used at a similar dosage (in terms of FPase activity) as the enzymatic cocktails produced by $T$. reesei.

From Figure 2, it can be seen that the amount of TRS increased with time, and that the effect was much more pronounced when the $A$. niger enzymes were used, compared to those from $T$. reesei. The superior performance of the $A$. niger enzymes was observed using both the whole fermentation media (WM) (Figure 2a) as well as the extracts (EE) obtained from the cultivations (Figure 2b). It is also interesting to note that the enzymes from $A$. niger performed as well as the commercial preparation during the SESB hydrolysis, while for both fungi, the results obtained using either the whole fermentation media or the extract were similar. The concentrations of TRS released after $72 \mathrm{~h}$ were 11.3 and $11.9 \mathrm{~g} \mathrm{~L}^{-1}$ for the A. niger WM and EE, respectively, while the corresponding values for $T$. reese $i$ were 3.5 and $3.9 \mathrm{~g} \mathrm{~L}^{-1}$, respectively.

When the commercial preparation was supplemented with the WM from either $T$. reesei or $A$. niger, the dosage of the commercial enzyme could be reduced by half, and still maintain a hydrolysis efficiency that was up to $36 \%$ more efficient in terms of total reducing sugar released (Figures 3a,b). Use of the commercial enzyme alone resulted in a TRS release of $10.7 \mathrm{~g} \mathrm{~L}^{-1}$, while 13.5 and $14.6 \mathrm{~g} \mathrm{~L}^{-1}$ of TRS were released using half the dosage of the commercial enzyme plus the WM from A. niger or T. reesei, respectively.

To better understand these results and provide a more detailed and quantitative comparison of the different hydrolysis conditions, the Chrastil approach for modeling enzymatic reactions, ${ }^{39}$ as described by Eq. 1, was used to fit the experimental data of reducing sugar released according to hydrolysis time. The Chrastil approach was chosen because 

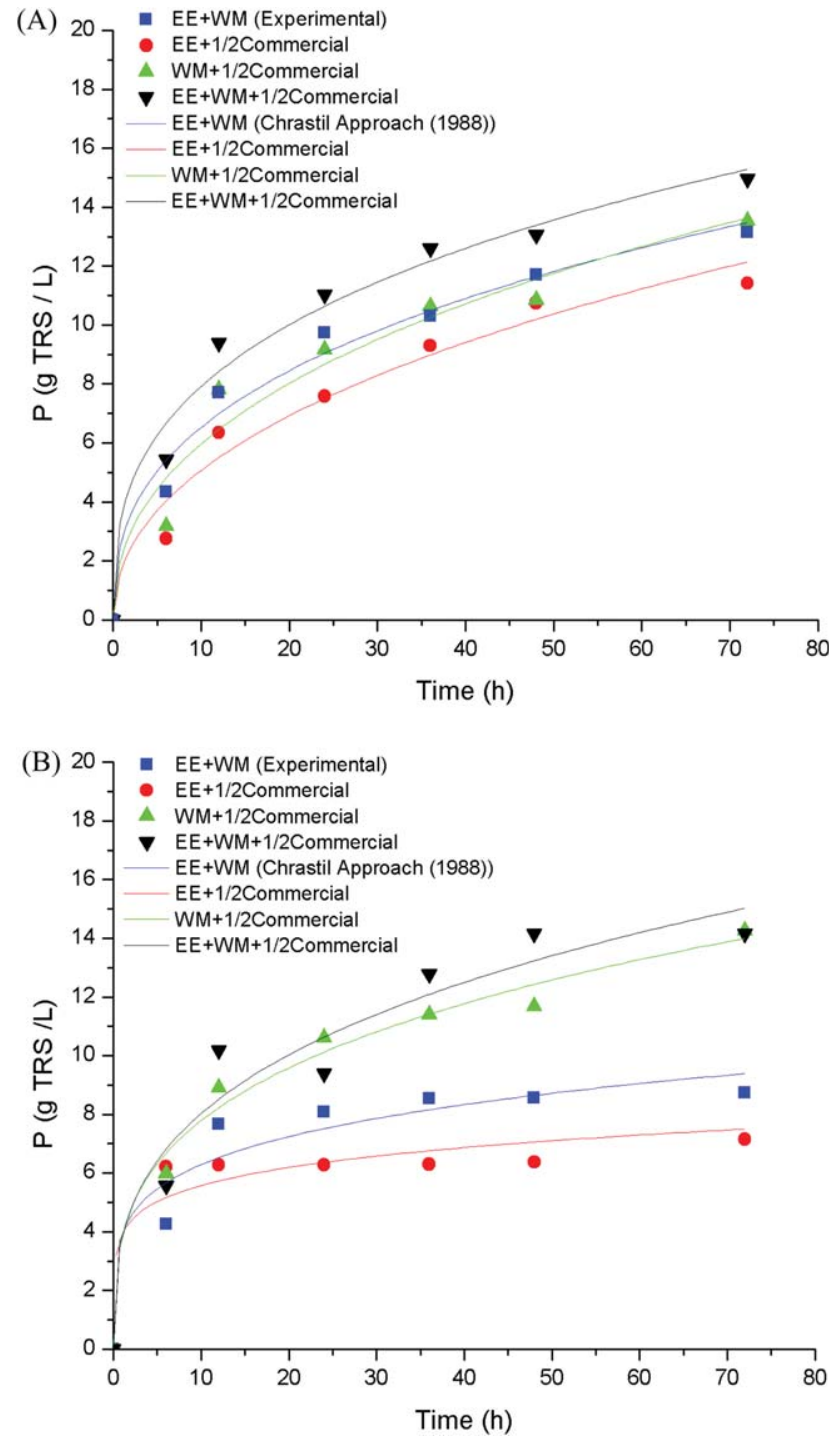

Figure 3. Temporal profiles of the concentrations of total reducing sugar released during the hydrolysis of pretreated sugarcane bagasse (SESB) using combinations of the whole fermentation media (WM), enzymatic extracts (EE), and the commercial enzyme preparation, for (A) A. niger 3T5B8 and (B) T. reesei Rut-C30.

it employs all the temporal data, instead of initial velocity, and is suitable for the analysis of heterogeneous structures, especially when the enzymatic reaction is diffusion limited. ${ }^{39}$ As highlighted by Carrillo et al., ${ }^{51}$ who used the Chrastil approach to evaluate the effect of alkali pretreatment on the hydrolysis of wheat straw cellulose, the kinetic and diffusion constants $(k$ and $n)$ obtained can provide important quantitative kinetic and structural information concerning the catalytic properties and overall sterical structure of the system, respectively. The semi-mechanistic model of Eq. 1 can be useful for understanding changes in the dynamics of the system during the reaction, especially when modeling long-term batch-type experiments that use highly heterogeneous substrates, such as the one used here. However, it is important to note that this model does not take into account inhibition effects, enzyme deactivation, or a decrease in substrate reactivity.

It can be seen from Eq. 1 that the parameters $k$ and $E_{0}$ are linearly dependent. A simultaneous regression for these
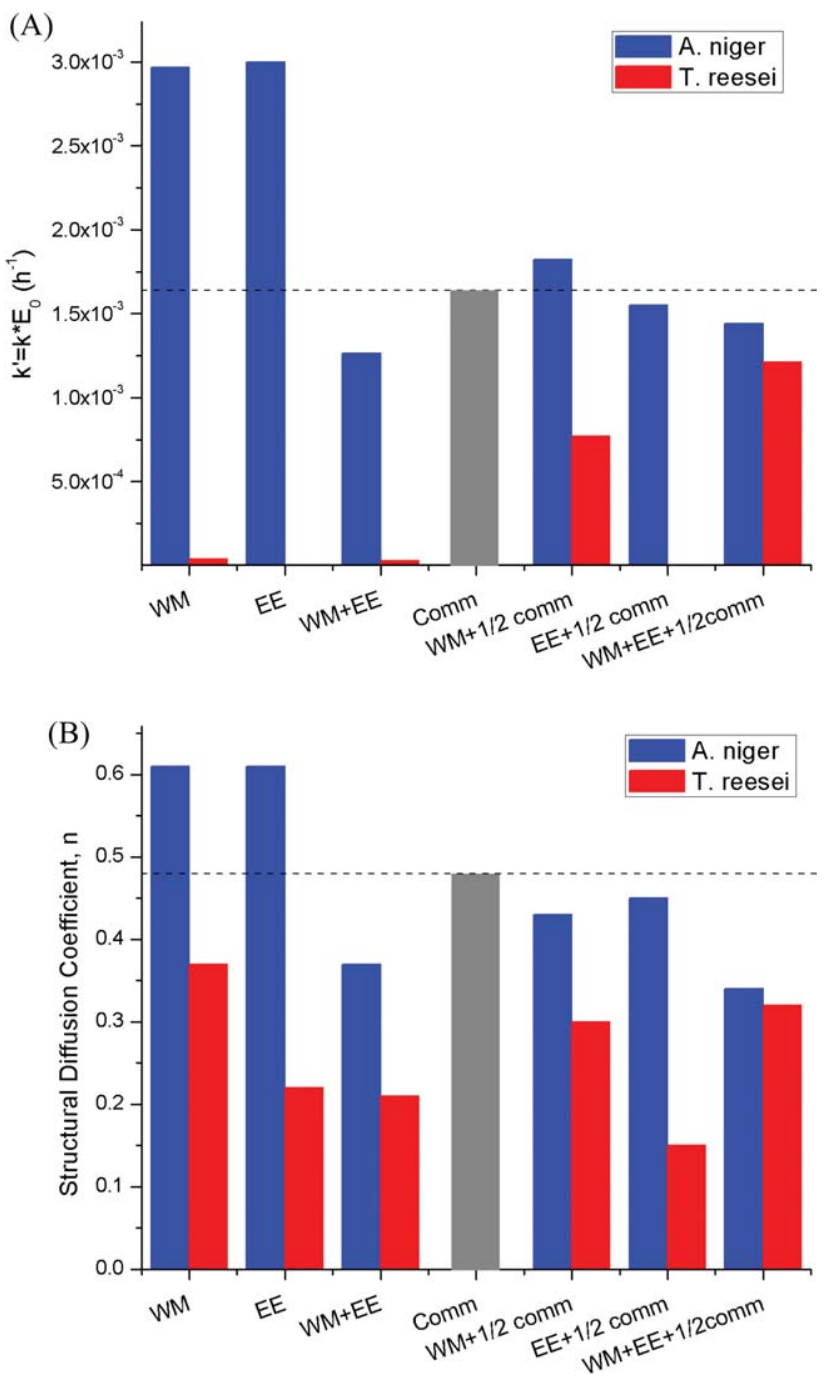

Figure 4. Values of the Chrastil model parameters, obtained by non-linear regression, for SESB hydrolyses using different enzyme sources. (A) specific velocity, $k^{\prime}$, of the system; (B) steric diffusion coefficient, $n$.

parameters would therefore produce a result that had little meaning, even though a good fit to the data might be achieved. Hence, in the present case $E_{0}$ was treated as a fixed parameter during the regression, and was assumed to be a measure of FPase activity (FPU/L). The FPase activities were the values shown in Table 3 , divided by $0.1 \mathrm{~L}$ (the total reaction volume). To estimate $E_{0}$ for the runs using the whole medium (WM), it was assumed that $\sim 20 \%$ of active enzymes were lost during extraction from the cultivation medium, as reported by Pirota et al., ${ }^{52}$ who analyzed successive SSF enzyme extractions under similar conditions. The activity values were summed in cases where the enzymes were derived from different sources. A better evaluation of the overall hydrolytic efficiency for each condition tested was achieved using the parameter $k^{\prime}$, which is the product of $k$ and $E_{0}$. Figure 4 presents the values of $k^{\prime}$ (Figure $4 a$ ) and $n$ (Figure $4 \mathrm{~b}$ ) for each fitting of the hydrolysis data obtained using the various enzymes sources (WM and EE from $A$. niger or T. reesei, and the commercial preparation), alone or in combination. All the regressions resulted in coefficients of multiple determination $\left(R^{2}\right) \geq 0.95$.

From Figure $4 \mathrm{a}$, it can be observed that the values of $k^{\prime}$ were much lower for $T$. reesei, except when the WM was 
used in combination with the commercial enzyme, indicative of the poor SESB hydrolysis capacity of the $T$. reese $i$ enzymes. The higher values of $k^{\prime}$ for the A. niger enzymes were indicative of better catalytic properties. This result was surprising, considering the lower $E_{0}$ value of the $A$. niger enzymes (measured in terms of FPase activity), compared to both the $T$. reesei enzymes and the commercial enzyme preparation (5.2-fold less activity in terms of FPase). A possible explanation for the superior performance of the $A$. niger enzymatic cocktail could be its higher xylanase activity (4.4-fold higher than for T. reesei, and 9.3-fold higher than the commercial preparation), as well as the higher $\beta$ glucosidase activity, compared to $T$. reesei (Table 3 ). The ratios between the activities of $\beta$-glucosidase and FPase were $145.7 \mathrm{IU} / \mathrm{FPU}$ for $A$. niger, $99.6 \mathrm{IU} / \mathrm{FPU}$ for the commercial enzyme, and only $1.54 \mathrm{IU} / \mathrm{FPU}$ for $T$. reesei, a value 100-fold lower than the ratio obtained for A. niger. According to Kovacs et al., ${ }^{19}$ even values of around 15-18 IU/FPU could be considered high. The importance of xylanase activity in the enzymatic cocktail is that it facilitates hydrolysis by increasing the accessibility of cellulose microfibrils to cellulose. ${ }^{53}$ Another possible explanation for the superior performance of the A. niger enzymatic cocktail could be related to the characteristics of the enzymes in terms of their degree of inhibition or deactivation caused by the phenolic compounds present in the SESB. Ximenes et al. ${ }^{50}$ reported that $\beta$-glucosidase from $A$. niger was the most resistant to inhibition and deactivation, requiring about 5-fold and 10fold higher concentrations, respectively, for the same levels of inhibition or deactivation observed for enzymes from $T$. reesei. In addition, it is also possible that other accessory enzymes that were not quantified here could have participated in the hydrolysis. The recent discovery of the important role of lytic polysaccharide monooxygenases (LPMO) and other accessory proteins in enhancing the degradation of cellulose has resulted in the inclusion of a new category in the CAZy database, called "auxiliary activities" (AA), which integrates a group of catalytic modules involved in plant cell wall degradation. ${ }^{54}$

The values of the parameter $n$ also reflected the superior hydrolytic capacity of the A. niger enzymes (Figure 4b). This dimensionless parameter is related to diffusion within the steric structure, and reflects the apparent order of the reaction. When the diffusion resistance is low, $n$ tends toward 1, and the reaction shows first order kinetics. If the system is strongly limited by diffusion resistance, the value of $n$ is small. ${ }^{51}$ All reactions that are diffusion-limited show $n<1$. The differences between the values of the structural diffusion resistance coefficient $n$ indicated that diffusion limitations during SESB hydrolysis were lower for the A. niger enzymatic cocktail, compared to the enzymes from either $T$. reesei or the commercial preparation. However, the significantly lower activity of $\beta$-glucosidase in the preparations from $T$. reesei (Table 3 ) could result in cellobiose accumulation and enzymatic inhibition, which might explain the inferior hydrolysis performance. As this model does not consider inhibition effects, the values of the parameters $k^{\prime}$ and $n$ obtained using the $T$. reesei enzymes alone should be considered with care, since they were probably influenced by product inhibition as well as by the diffusive characteristics of the product-substrate system.

Overall, the values of $k^{\prime}$ and $n$ are very consistent with the experimental results obtained for the SESB hydrolysis. The higher values obtained for $k^{\prime}$ and $n$ using the enzymes from
A. niger are in agreement with the superior performance during SESB hydrolysis, compared to the $T$. reesei enzymes. Even though description of the kinetics of enzymatic hydrolysis of insoluble materials can be a very complex process, use of the Chrastil approach for modeling the enzymatic hydrolysis of SESB proved to be very useful in terms of generation of quantitative parameters that enabled a more detailed comparison of the kinetic characteristics of the different enzyme sources. The $k$ and $n$ values obtained here are of the same order of magnitude as those reported by Carrillo et al. $^{51}$ for alkali-treated wheat straw samples, even though the biomass, enzymes, and process conditions were different. This indicates that the Chrastil approach can be a valuable tool for comparing the performance of different procedures during the enzymatic hydrolysis of vegetal biomass.

From a practical point of view, another comparison of the SESB hydrolysis performance using A. niger and T. reesei enzymes can be carried out by analyzing the enzyme loadings used in terms of the total amount of enzyme protein added into the reactor system as $\mathrm{mg}$ protein/g glucan (i.e., the cellulose fraction of SESB). For the hydrolysis experiments using the enzymes from either A. niger or T. reesei alone, the enzyme loadings in terms of total protein were very similar (8.2 $\mathrm{mg}$ protein/g glucan for A. niger and 10.9 $\mathrm{mg}$ protein/g glucan for $T$. reesei). Therefore, it can be inferred that the superior performance of the A. niger enzymes on SESB hydrolysis is probably related to the higher specific activity of different enzymes such as xylanases (6-folds higher) and $\beta$-glucosidases (25-folds higher) in comparison to $T$. reesei enzymes. It is also worth to mention that these enzyme loading values are very compatible with the current level being reported in the literature for lignocellulosic biomass hydrolysis. ${ }^{48}$

\section{Steam-exploded sugarcane bagasse (SESB) hydrolysis in terms of total conversion}

An analysis was undertaken of the total sugars released (in terms of both glucose and total reducing sugar) at the end of the SESB hydrolysis. Figure 5 summarizes the conversion percentages achieved after $72 \mathrm{~h}$ of SESB hydrolysis using the A. niger (Figure 5a) and T. reesei (Figure 5b) enzymes from either the extracts (EE) or the whole fermentation media (WM), compared to use of the commercial enzyme cocktail as well as combinations of the different enzyme sources.

Use of the enzymatic complexes from A. niger (Figure 5a) for SESB hydrolysis resulted in similar biomass conversion yields for EE and WM, in terms of both glucose (18.5 and $16.7 \%$ of the theoretical yields for $\mathrm{EE}$ and WM, respectively) and total reducing sugar (33.6 and 35.3\% for EE and $\mathrm{WM}$, respectively). The values were not significantly different (Tukey's test, $P<0.05$ ). It is important to note the good correlation between the release of glucose and total reducing sugar, which could be an indication that the $\beta$-glucosidase activity levels were sufficient for the formation of monomeric sugars. In addition, use of the enzymatic complex from $A$. niger resulted in conversion yields similar to those achieved using the commercial enzyme preparation (14.0 and $31.9 \%$ of the theoretical yields in terms of glucose and TRS). This is an interesting finding, especially considering that the dosage of enzymes (in terms of FPase activity) in the commercial cocktail was up to 6.2-fold higher than in the EE from A. niger. 

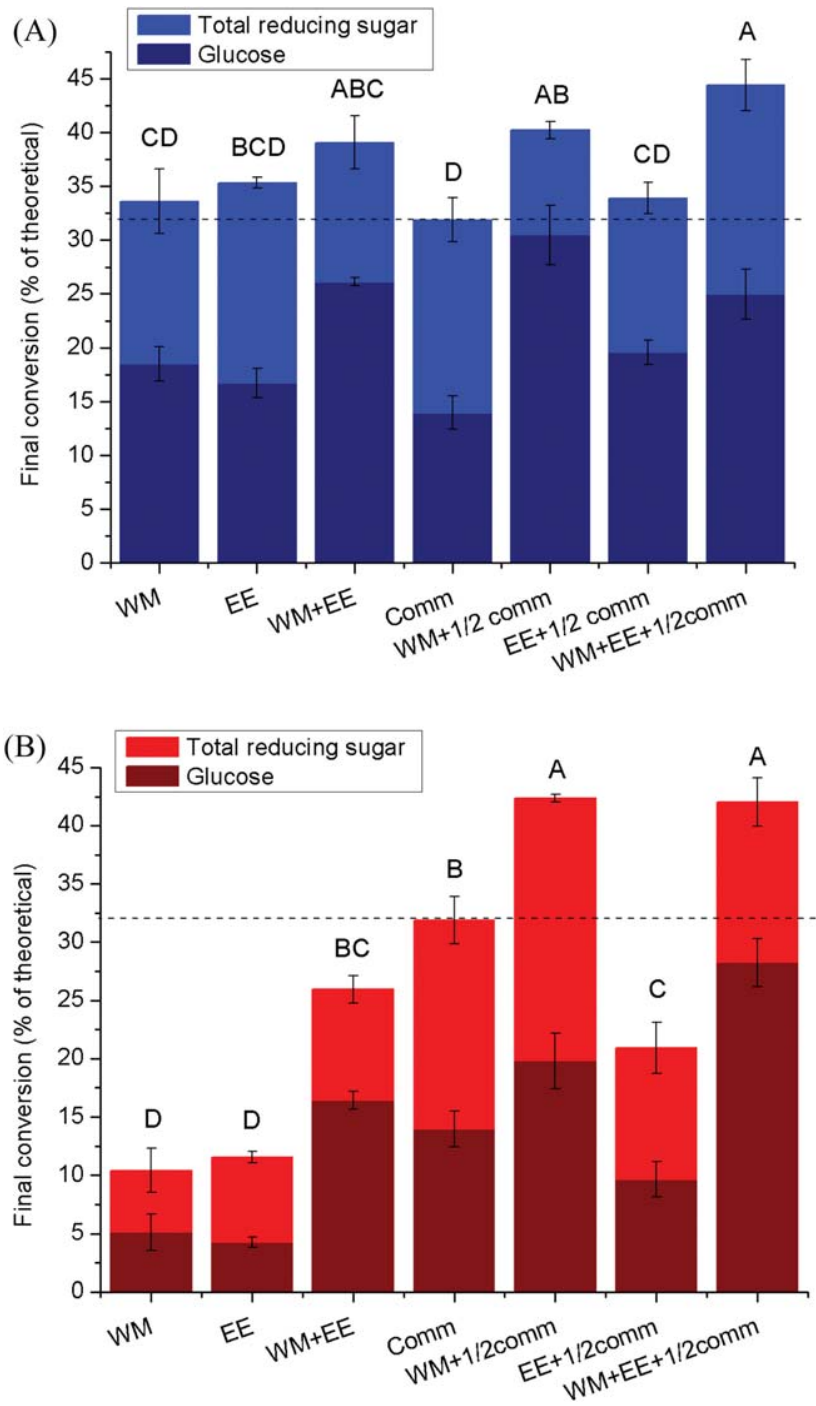

Figure 5. Kinetic profiles of enzyme production over a period of $120 \mathrm{~h}$ under SSF for (A) A. niger 3T5B8 and (B) T. reesei Rut-C30.

For the hydrolyses carried out using different combinations of $A$. niger enzymes (EE and $\mathrm{WM}$ ) and a low dosage of commercial enzymes (Figure 5a), it is interesting to note that higher conversion yields were achieved when the whole medium was present. Considering that the sugars released from the wheat bran in the whole medium were already subtracted, since it was used as one of the controls, it is possible that enzymes that remained adsorbed to the fermented medium (mycelium-bound enzymes) were active during the saccharification step, hence improving SESB conversion. In this set of experiments (Figure 5a), higher conversion values (25.0\% in terms of glucose and $44.4 \%$ in terms of TRS) were achieved using a combination of A. niger enzymes from the EE and WM, together with a low dosage of commercial enzymes. Nevertheless, the yields were not statistically different from those obtained using a combination of WM and EE enzymes from $A$. niger cultivated under SSF, or using the WM enzymes supplemented with a low dosage of the commercial enzymes.

For SESB hydrolysis using the enzymatic complex from $T$. reesei (Figure $5 \mathrm{~b}$ ), the trends were similar to those observed for A. niger. However, the conversion yields were substantially lower than those achieved with either the A. niger enzymes or the commercial enzymes. Similar conversion values were obtained for the $T$. reesei EE and WM, in terms of both glucose $(4.3$ and $5.1 \%$ of the theoretical yields for the $\mathrm{EE}$ and the WM, respectively) and total reducing sugar (11.6 and $10.4 \%$, respectively). Nevertheless, higher conversion values $(28.2 \%$ of the theoretical yield in terms of glucose and $42.0 \%$ in terms of TRS) were achieved using a combination of $T$. reesei enzymes from the WM and a low dosage of commercial enzymes. Further addition of $T$. reesei EE to the combination of the WM and a low dosage of commercial enzymes resulted in similar conversion yields. Kovacs et al. ${ }^{19}$ also observed an improvement in hydrolytic capacity when the whole fermentation broths were used instead of the supernatants from $T$. reese $i$ and $T$. atrovide cultivations under submerged fermentation. The improvement in the hydrolysis of pretreated spruce was attributed to the presence of myceliumbound enzymes. Higher performance using the whole broth of $T$. reesei instead of the filtrate was also reported by Schell et al. $^{18}$ for a simultaneous saccharification and fermentation process, where higher ethanol yields were achieved using the whole broth. The present findings demonstrate that the use of in-house WM enzymes from SSF, combined with a low dosage of commercial cellulases, may be of potential interest for biotechnological processes involving the conversion of sugarcane bagasse into fuels and chemicals.

In summary, for both fungi, the enzymatic extract (EE) and the whole fermentation medium (WM) provided similar SESB hydrolysis yields, in terms of both glucose and total reducing sugar, giving a clear indication that the SSF enzyme extraction step could be eliminated. It is therefore possible to use a lignocellulosic agricultural waste for enzyme production under SSF, and to use it again during the saccharification step, eliminating the enzyme extraction/filtration steps. This procedure is highly advantageous in terms of reduced enzyme and process costs, and also avoids the generation of unnecessary effluent streams. Moreover, the proposed enzyme production process, with in-house enzyme production under SSF, followed by application of the whole fermentation medium in the biomass saccharification step to generate the sugars needed for the production of biofuel and other chemicals, offers a potential alternative for sustainable industrial biomass conversion within the biorefinery concept.

Comparison of the enzymatic conversion yields obtained using the enzymes from the two fungi revealed the superiority of the A. niger 3T5B8 enzymatic complex, which provided conversion values that were up to 3.2-fold higher (in terms of TRS) than those obtained using $T$. reesei Rut-C30 at very similar enzyme loadings ( $8.2 \mathrm{mg}$ protein/g glucan for $A$. niger and $10.9 \mathrm{mg}$ protein/g glucan for $T$. reesei). However, it is important to note that with supplementation of the $T$. reesei enzymes present in the WM it was possible to achieve conversion values that were similar to those achieved using $A$. niger enzymes. Although much work remains to scale up the proposed procedure, the conversion yields are very promising, especially given the relatively low enzyme dosages used in the hydrolyses. The findings highlight the potential of inhouse SSF enzyme production, followed by application of the whole medium in the saccharification step, as a process configuration worthy of further investigation.

\section{Conclusions}

The A. niger 3T5B8 strain cultivated under SSF was able to produce an enzymatic cocktail that was more efficient for 
hydrolysis of SESB, compared to the enzymes from either $T$. reesei Rut-C30 or a commercial preparation at a similar FPase activity dosage. Furthermore, SESB hydrolysis using either extract supernatant or whole fermentation medium resulted in similar yields in terms of glucose and total reducing sugar, giving a clear indication that the enzyme extraction/filtration steps in SSF could be eliminated. The proposed procedure is cost-effective and avoids unnecessary generation of effluents. The enzymatic conversion of SESB using whole SSF fermentation media is a potential alternative process configuration that conforms to the biorefinery concept.

\section{Acknowledgments}

The authors would like to thank Embrapa, CNPq, Capes, and FAPESP (all from Brazil) for their financial support. They also acknowledge Dr. Sonia Couri as the researcher responsible for the isolation and mutation studies of the $A$. niger 3T5B8 strain, and are grateful to Dr. Sandra C. Pereira for internal review of this article.

\section{Literature Cited}

1. Delabona P, Pirota R, Codima C, Tremacoldi C, Rodrigues A, Farinas C. Using Amazon forest fungi and agricultural residues as a strategy to produce cellulolytic enzymes. Biomass Bioenergy. 2012;37:243-250.

2. King BC, Waxman KD, Nenni NV, Walker LP, Bergstrom GC, Gibson DM. Arsenal of plant cell wall degrading enzymes reflects host preference among plant pathogenic fungi. Biotechnol Biofuels. 2011;4:14.

3. Amore A, Pepe O, Ventorino V, Birolo L, Giangrande C, Faraco V. Industrial waste based compost as a source of novel cellulolytic strains and enzymes. Fems Microbiol Lett. 2013; 339:93-101.

4. Cunha FM, Esperanca MN, Zangirolami TC, Badino AC, Farinas CS. Sequential solid-state and submerged cultivation of Aspergillus niger on sugarcane bagasse for the production of cellulase. Bioresour Technol. 2012;112:270-274.

5. Pirota RDPB, Tonelotto M, Delabona PD, Fonseca RF, Paixao DAA, Baleeiro FCF, Neto VB, Farinas CS. Enhancing xylanases production by a new Amazon Forest strain of Aspergillus oryzae using solid-state fermentation under controlled operation conditions. Indus Crops Prod. 2013;45:465-471.

6. Lan TQ, Wei D, Yang ST, Liu XG. Enhanced cellulase production by Trichoderma viride in a rotating fibrous bed bioreactor. Bioresour Technol. 2013;133:175-182.

7. Weiss N, Borjesson J, Pedersen LS, Meyer AS. Enzymatic lignocellulose hydrolysis: improved cellulase productivity by insoluble solids recycling. Biotechnol Biofuels. 2013;6:14.

8. Waeonukul R, Kosugi A, Prawitvvong P, Deng L, Tachaapaikoon C, Pason P, Ratanakhanokchai K, Saito M, Mori Y. Novel cellulase recycling method using a combination of Clostridium thermocellum cellulosomes and Thermoanaerobacter brockii beta-glucosidase. Bioresour Technol. 2013;130: 424-430.

9. Rodrigues AC, Leitao AF, Moreira S, Felby C, Gama M. Recycling of cellulases in lignocellulosic hydrolysates using alkaline elution. Bioresour Technol. 2012;110:526-533.

10. Delabona P, Farinas C, da Silva M, Azzoni S, Pradella J. Use of a new Trichoderma harzianum strain isolated from the Amazon rainforest with pretreated sugar cane bagasse for on-site cellulase production. Bioresour Technol. 2012;107:517-521.

11. Sorensen A, Teller PJ, Lubeck PS, Ahring BK. Onsite enzyme production during bioethanol production from biomass: screening for suitable fungal strains. Appl Biochem Biotechnol. 2011; 164:1058-1070.

12. Kovacs K, Macrelli S, Szakacs G, Zacchi G. Enzymatic hydrolysis of steam-pretreated lignocellulosic materials with Trichoderma atroviride enzymes produced in-house. Biotechnol Biofuels. 2009;2:11.
13. Lynd L, Weimer P, van Zyl W, Pretorius I. Microbial cellulose utilization: fundamentals and biotechnology. Microbiol Mol Biol Rev. 2002;66:506.

14. de Souza WR, de Gouvea PF, Savoldi M, Malavazi I, Bernardes LAD, Goldman MHS, de Vries RP, Oliveira JVD, Goldman GH. Transcriptome analysis of Aspergillus niger grown on sugarcane bagasse. Biotechnol Biofuels. 2011;4:16.

15. Barrios-Gonzalez J. Solid-state fermentation: physiology of solid medium, its molecular basis and applications. Process Biochem. 2012;47:175-185.

16. Singhania RR, Sukumaran RK, Patel AK, Larroche C, Pandey A. Advancement and comparative profiles in the production technologies using solid-state and submerged fermentation for microbial cellulases. Enzyme Microbial Technol. 2010;46:541-549.

17. Raimbault R. General and microbiological aspects of solid substrate fermentation. Eletron J Biotechnol. 1998;1:3-45.

18. Schell DJ, Hinman ND, Wyman CE, Werdene PJ. Whole broth cellulase production for use in simultaneous saccharification and fermentation. Appl Biochem Biotechnol. 1990;24/25:287-297.

19. Kovacs K, Szakacs G, Zacchi G. Comparative enzymatic hydrolysis of pretreated spruce by supernatants, whole fermentation broths and washed mycelia of Trichoderma reesei and Trichoderma atroviride. Bioresour Technol. 2009;100:1350-1357.

20. Xia LM, Shen XL. High-yield cellulase production by Trichoderma reesei ZU-02 on corn cob residue. Bioresour Technol. 2004;91:259-262.

21. Amorim HV, Lopes ML, Oliveira JVD, Buckeridge MS, Goldman GH. Scientific challenges of bioethanol production in Brazil. Appl Microbiol Biotechnol. 2011;91:1267-1275.

22. Rocha GJM, Martin C, da Silva VFN, Gomez EO, Goncalves AR. Mass balance of pilot-scale pretreatment of sugarcane bagasse by steam explosion followed by alkaline delignification. Bioresour Technol. 2012;111:447-452.

23. Rabelo SC, Rossell CEV, Rocha GJD, Zacchi G. Enhancement of the enzymatic digestibility of sugarcane bagasse by steam pretreatment impregnated with hydrogen peroxide. Biotechnol Prog. 2012;28:1207-1217.

24. Kaar WE, Gutierrez CV, Kinoshita CM. Steam explosion of sugarcane bagasse as a pretreatment for conversion to ethanol. Biomass Bioenergy. 1998;14:277-287.

25. da Cruz SH, Dien BS, Nichols NN, Saha BC, Cotta MA. Hydrothermal pretreatment of sugarcane bagasse using response surface methodology improves digestibility and ethanol production by SSF. J Indus Microbiol Biotechnol. 2012;39:439-447.

26. Diedericks D, van Rensburg E, Garcia-Aparicio MD, Gorgens JF. Enhancing the enzymatic digestibility of sugarcane bagasse through the application of an ionic liquid in combination with an acid catalyst. Biotechnol Prog. 2012;28:76-84.

27. da Silva AS, Teixeira RSS, Endo T, Bon EPS, Lee SH. Continuous pretreatment of sugarcane bagasse at high loading in an ionic liquid using a twin-screw extruder. Green Chem. 2013;15: 1991-2001.

28. Karatzos SK, Edye LA, Doherty WOS. Sugarcane bagasse pretreatment using three imidazolium-based ionic liquids: mass balances and enzyme kinetics. Biotechnol Biofuels. 2012;5:62.

29. Rocha GJD, Martin C, Soares IB, Maior AMS, Baudel HM, de Abreu CAM. Dilute mixed-acid pretreatment of sugarcane bagasse for ethanol production. Biomass Bioenergy. 2011;35: 663-670.

30. de Vasconcelos SM, Santos AMP, Rocha GJM, Souto-Maior AM. Diluted phosphoric acid pretreatment for production of fermentable sugars in a sugarcane-based biorefinery. Bioresour Technol. 2013;135:46-52.

31. Rabelo SC, Maciel R, Costa AC. Lime pretreatment and fermentation of enzymatically hydrolyzed sugarcane bagasse. Appl Biochem Biotechnol. 2013;169:1696-1712.

32. Mesa L, Gonzalez E, Cara C, Gonzalez M, Castro E, Mussatto SI. The effect of organosolv pretreatment variables on enzymatic hydrolysis of sugarcane bagasse. Chem Eng J. 2011;168: $1157-1162$.

33. Mendes FM, Siqueira G, Carvalho W, Ferraz A, Milagres AMF. Enzymatic hydrolysis of chemithermomechanically pretreated sugarcane bagasse and samples with reduced initial lignin content. Biotechnol Prog. 2011;27:395-401. 
34. de Souza AP, Leite DCC, Pattahil S, Hahn MG, Buckeridge MS. Composition and structure of sugarcane cell wall polysaccharides: implications for second-generation bioethanol production. Bioenerg Res. 2012;6:564-579.

35. Giese EC, Pierozzi M, Dussan KJ, Chandel AK, da Silva SS. Enzymatic saccharification of acid-alkali pretreated sugarcane bagasse using commercial enzyme preparations. J Chem Technol Biotechnol. 2013;88:1266-1272.

36. Delabona PD, Cota J, Hoffmam ZB, Paixao DAA, Farinas CS, Cairo J, Lima DJ, Squina FM, Ruller R, Pradella JGD. Understanding the cellulolytic system of Trichoderma harzianum P49P11 and enhancing saccharification of pretreated sugarcane bagasse by supplementation with pectinase and alpha-L-arabinofuranosidase. Bioresour Technol. 2013;131:500-507.

37. Rodriguez-Zuniga UF, Couri S, Neto VB, Crestana S, Farinas CS. Integrated strategies to enhance cellulolytic enzyme production using an instrumented bioreactor for solid-state fermentation of sugarcane bagasse. Bioenergy Res. 2013;6:142-152.

38. Mandels M, Sternberg D. Recent advances in cellulase technology. J Ferment Technol. 1976;54:267-286.

39. Chrastil J. Enzymic product formation curves with the normal or diffusion limited reaction-mechanism and in the presence of substrate receptors. Int J Biochem. 1988;20:683-693.

40. Bailey MJ, Poutanen K. Production of xylanolytic enzymes by strains of aspergillus. Appl Microbiol Biotechnol. 1989;30:5-10.

41. Miller G. Use of dinitrosalicylic acid reagent for determination of reducing sugar. Anal Chem. 1959;31:426-428.

42. Bradford M. Rapid and sensitive method for quantitation of microgram quantities of protein utilizing principle of proteindye binding. Anal Biochem. 1976;72:248-254.

43. Delabona PD, Pirota R, Codima CA, Tremacoldi CR, Rodrigues A, Farinas CS. Effect of initial moisture content on two Amazon rainforest Aspergillus strains cultivated on agro-industrial residues: biomass-degrading enzymes production and characterization. Indus Crops Prod. 2013;42:236-242.
44. Pal A, Khanum F. Production and extraction optimization of xylanase from Aspergillus niger DFR-5 through solid-statefermentation. Bioresour Technol. 2010;101:7563-7569.

45. Singhania RR, Sukumaran RK, Pandey A. Improved cellulase production by Trichoderma reesei RUT C30 under SSF through process optimization. Appl Biochem Biotechnol. 2007;142:60 70

46. Jecu L. Solid state fermentation of agricultural wastes for endoglucanase production. Indus Crops Prod. 2000;11:1-5.

47. Gusakov AV. Alternatives to Trichoderma reesei in biofuel production. Trends Biotechnol. 2011;29:419-425.

48. Kim Y, Ximenes E, Mosier NS, Ladisch MR. Soluble inhibitors/deactivators of cellulase enzymes from lignocellulosic biomass. Enzyme Microb Technol. 2011;48:408-415.

49. Ximenes E, Kim Y, Mosier N, Dien B, Ladisch M. Inhibition of cellulases by phenols. Enzyme Microb Technol. 2010;46:170-176.

50. Ximenes E, Kim Y, Mosier N, Dien B, Ladisch M. Deactivation of cellulases by phenols. Enzyme Microb Technol. 2011;48:54 60

51. Carrillo F, Lis MJ, Colom X, Lopez-Mesas M, Valldeperas J. Effect of alkali pretreatment on cellulase hydrolysis of wheat straw: kinetic study. Process Biochem. 2005;40:3360-3364.

52. Pirota R, Miotto LS, Delabona PS, Farinas CS. Improving the extraction conditions of endoglucanase produced by Aspergillus niger under solid-state fermentation. Braz J Chem Eng. 2013; 30:117-123.

53. Kumar R, Wyman CE. Effect of xylanase supplementation of cellulase on digestion of corn stover solids prepared by leading pretreatment technologies. Bioresour Technol. 2009;100:42034213.

54. Levasseur A, Drula E, Lombard V, Coutinho PM, Henrissat B. Expansion of the enzymatic repertoire of the CAZy database to integrate auxiliary redox enzymes. Biotechnol Biofuels. 2013;6:14.

Manuscript received Aug. 6, 2013, and revision received Sept. 13, 2013. 